\title{
"THE HOWELLS FAMILY"
}

\author{
BY RICHARD J. HINTON
}

\section{EDITED BY CLARA M. KIRK AND RUDOLF KIRK}

The following account of "The Howells Family" is here reprinted for the first time since its appearance, on July 15, 1897, in The Voice, a New York temperance paper of the last century. This description of the family, which is practically unknown to Howells scholars, is interesting to us because it is written by " $A$ Friend of the Family," Richard Josiah Hinton, who knew personally every member of the group. Had it not been clipped by an enthusiastic Howells reader of the I890's, Mary Magruder of Sandy Spring, Maryland, and presented to the present writers, it might have remained lost in the files of The Voice. The article has now been added to the growing collection of Howells material in the Rutgers University Library.

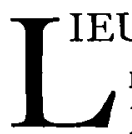

IEUTENANT Richard J. Hinton, an ardent abolitionist, first met William Dean Howells early in I86I, at the Howells' home in Jefferson, Ohio. Both of these young journalists were, as Hinton says, "deeply immerst in Northern and stalwart agitation" and both had recently published campaign lives of Abraham Lincoln. A few years before their meeting, Hinton had travelled to Kansas to join John Brown in anti-slavery agitation; Howells had breathed the fervid atmosphere of the little "Underground Railway" town of Jefferson, since his father had set up his printing press there in I 852. William Cooper Howells, staunch Whig that he was, had frequently aided John Brown, his sons and his followers, harboring them in the loft of his newspaper office. The elder Howells belonged to the "Sons of Liberty," organized by Joshua Reed Giddings in I 859 with the purpose of encouraging Ohio to secede from the Union in protest over the slavery issue. Only John Brown's unexpected attack on Harper's Ferry put an end to this plot. ${ }^{1}$ It is to be supposed that Howells and Hinton had much to discuss when they first met early in I 86r. When they met again the following September, they were bound in opposite directions-Howells to Italy, to become American consul in Venice, and Hinton to the "distant West," as the first white officer in the Union Army to command Negro troops. Hinton's recollections of the meeting, more than thirty-five years later, were "faint but lasting," reinforced, as he tells us, by the political sympathies of the two young reporters and kept alive by

${ }^{1}$ E. C. Lampson, "William Dean Howells," Ohio Journalism Hall of Fame, Columbus: The Ohio State University Press, I 929, pp. 26-29. 
the many references to William Dean, during the intervening years, by other members of the family. Nor did the two men altogether lose personal contact, for Hinton published at least one article in The Atlantic Monthly while Howells was editor.

In I897, at the time of the publication of these reminiscences, Howells was well known as editor, first, of The Atlantic Monthy, and then, of Harper's "Editor's Study." He was an established novelist, dramatist, and critic, and had, only a few months earlier, made a triumphal lecture tour of the West. Hinton's mind, however, returned to the "grave but pleasant-faced" young man whom he had known in the stirring days of the Civil War. Hinton himself had, since that time, become the author of many articles and of half a dozen books, among the most famous of which was John Brown and His Men (1 894). ${ }^{2}$ Hinton's sustained belief in human liberties was certainly strengthened by "An Old Pioneer American Household of the Altrurian Stock."

The inaccuracies of several of Hinton's dates, as indicated in the notes below, suggest that he did not avail himself of Howells' own memories of this period, in My Literary Passions (1 895), when he sketched his picture of "The Howells Family."

\section{The Howells Family.}

An Old Pioneer American Household of the Altrurian StockWilliam Dean and His Parentage.

New and Interesting Side-Lights upon the Early Career of the Novelist, Poet, Essayist, William Dean Howells, by a Friend of the Family-The Typical American Pioneer Family in the Central West-Three Generations of Editors-Keen and Vigorous Intellectuality of the Howells-Beautiful Home Life and Influence-Their Care for the Dependent Brother.

The Western Reserve has almost lost its peculiar associations to all but Americans of sunset days. The issues which made it famous are fast becoming memories only.

Jefferson was for a generation almost as noted an historical village, tho, as Concord or Lexington. It is but a village-this Ohio anti-slavery centerlying off "main-traveled roads" also. It was on a by-way, with less than 700 inhabitants, when William Dean Howells was a dreamy and serious youth. It has about reacht its thousand, and is still a cross-country place.

${ }^{2}$ William E. Connelley, "Col. Richard J. Hinton," Transactions of the Kansas State Historical Society, Vol. VII, I 901-1902. Topeka, r 902, pp. 486-493.

1 This everyday phrase echoes the title of Hamlin Garland's novel, Main Travelled Roads, I 89 I. 
No "pent-up Utica," however, could contract the powers of the country editor, William Cooper Howells, who, with his wife, Mary Dean, and eight children, a printing outfit, type, hand-press, etc., large enough for a weekly newspaper-office, moved during $1854^{3}$ into the little village and county seat of Ashtabula, the northeast division of the famous Ohio Western Reserve. Small as was and is the town of Jefferson, it was large enough to be the home, not only of the Howells family since that date, but to hold also among its citizens famous Northern statesmen of the rank for that time of Joshua R. Giddings and Benjamin Franklin Wade, ${ }^{4}$ respectively among the boldest of political anti-slavery and free-soil leaders. The New England makers of the Western Reserve not only bred men of mark and women of character, but in aid of their community-building and its free institutions came the Northwest Ordinance ${ }^{5}$ and the subsequent creation of more than a score of free commonwealths. Into such an environment moved this Welsh-born, Quaker-bred American, and pioneer-raised printer and editor-a man of the Franklin mold, having but little of the "Poor Richard" side, however, and much of gentle scholarship, earnest conviction, and poetic insight, with a devout mysticism which led him to a profound faith in the "celestial" theology and philosophy of Emanuel Swedenborg. ${ }^{6}$ Withal, there was the sane common sense that attends on sweet humor and grows from a lively wit. To have held firmly to Swedenborg was certainly a distinguishing mark in communities that were molded by Calvinism, and almost extinguisht, too, it may be said without mocking intent, in that contrariety of conflicting concepts which produced "Millerism" or "Adventistism"; ${ }^{7}$ witnest the first strange throes of Mormonism; gave place to the "Prophet" Mathews, ${ }^{8}$ and encouraged as strange a medley of theophanic outgivings as it were possible to concentrate into so narrow a compass.

The Ashtabula Sentinel, when Mr. Howells, Sr., bought a half interest (afterwards completing the entire purchase), was a moderate Whig paper. $\mathrm{He}$ soon changed it into a strong Republican advocate.

The family consisted, besides the parents, at the time of their Jefferson settlement, of five sons, Joseph, William Dean, Henry, Samuel Cooper, and

2 No pent-up Utica contracts your powers,

But the whole boundless continent is yours.

"Epilogue to [Addison's] Cato," by Jonathan Mitchell Sewall (1748-1808).

${ }^{3}$ This date is incorrect. William Cooper Howells began his work on the Ashtabula Sentinel in 1851 . He became editor of the paper in 1852 . On January 1,1853 , he became half owner of the Sentinel, which he moved to Jefferson.

${ }^{4}$ Joshua Reed Giddings (1795-1864) and Benjamin Franklin Wade (1800-1878) were law partners in Jefferson, Ohio, for a time. Wade was later United States Senator from Ohio.

${ }^{5}$ This was the Ordinance of 1787 , whereby the territory northwest of the Ohio River was set aside for settlement according to certain stipulated regulations.

${ }^{6}$ Emanuel Swedenborg (I688-r772) was a Swedish scientist, philosopher, and theologian. Swedenborgianism was the religious philosophy of the Howells family.

7William Miller (1 783-1 849) founded the Second Adventist religious sect; also called "Millerites."

${ }^{8}$ Robert Matthews (born about 1790 -died after I 840 ). See Appleton's Cyclopedia of American Biography IV, 262, s.v. "Matthias"; and William L. Stone, Matthias and" His Impostures, New York, 1835. 
John Butler-the last being but seven years of age,-with three daughters, Victoria, Amelia, ${ }^{9}$ and Annie. The youngest of the sons died, a student, in his I 8 th year, at Cleveland. Young as he was, he had commanded a company of stalwart school-fellows who tendered their services, which were accepted too, when in $\mathbf{I} 864$ Cincinnati was threatened with a Confederate attack. The eldest

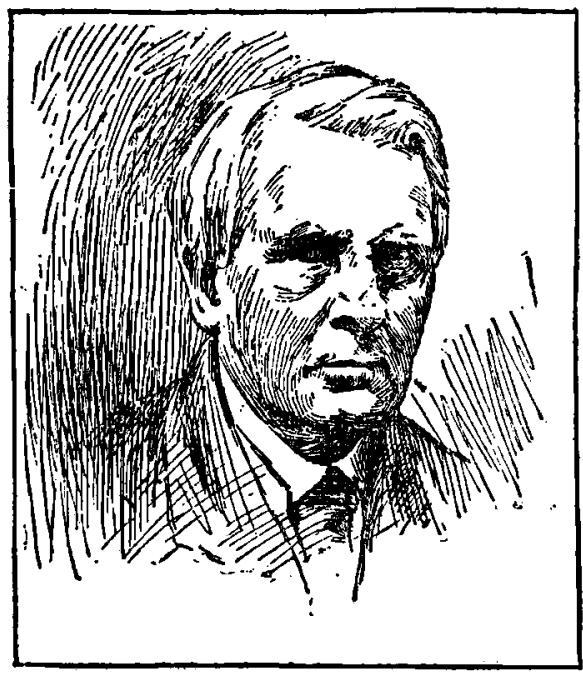

W. c. HOWELLS.

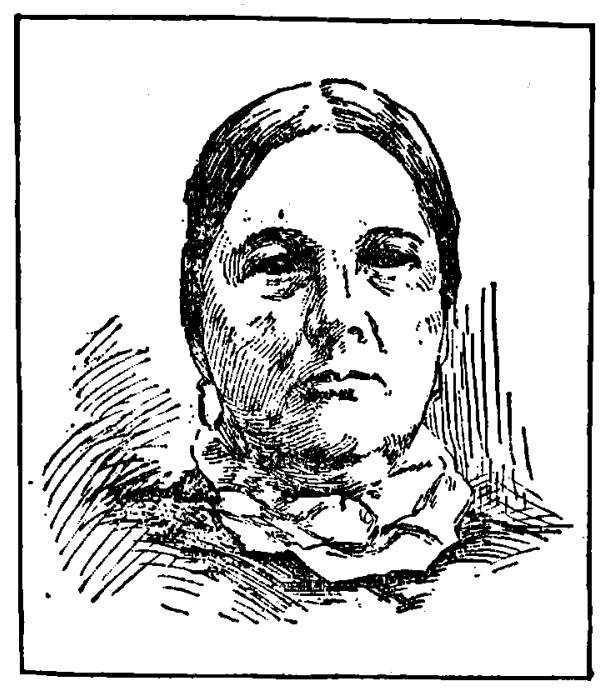

Mzs. w. C. nowells.

daughter (Mrs. Mulholland) ${ }^{10}$ died in Virginia, Dec. 3, I 886. The youngest is Mrs. Achille Fréchette, and resides at Ottawa, Canada. Miss Amelia Howells lives in the family home at Jefferson, caring tenderly and devotedly in his elder years for her brother Henry, as mother, father, and sisters have all done through the long-drawn days of his dependent and aimless life.

The care of this unfortunate brother ${ }^{11}$ - whose brain was permanently disjoined in childhood by fever and an accident - is one of the most touching of incidents - for close, unbroken, and tenderest of care. She has waited, almost three score years, upon this helpless but strikingly handsome member of the Howells family, whose splendidly formed head recalls to all who have seen it the superb Vatican bust of Caesar Augustus. It is almost impossible to express in words that will not invade the delicacy of friendship and the sacred privacy of the innermost home life, one's sense of this abiding love, this tenderest and most faithful of service and devotion. All of the Howells family participate therein.

9 This is a misprint for Aurelia.

${ }^{10}$ Victoria Howells, William Dean's oldest sister, who died in 1886 , married a $\mathrm{Mr}$. Mulholland.

${ }^{11}$ Henry Howells was hit by a baseball bat when he was four years old. 
The editor served a long apprenticeship to his craft, which began in 1831 at St. Clairsville, ${ }^{12}$ Steuben county, Ohio, and did not end till The Sentinel was wholly surrendered to Joseph A. Howells, the eldest son, in I 884 - over half a century of unremitting work. Joseph has been and still is the editor. ${ }^{13} \mathrm{He}$ has been, from the removal to Jefferson in $1854,{ }^{14}$ foreman, publisher, and associate editor. His eldest son $^{15}$ is now publisher, and will succeed his father as editor. This is a fairly stalwart family record-65 years, so far, of such work in one direct line and by three of its generations. ${ }^{16}$ If the editorial labors of Samuel and William Dean on other Ohio newspapers ${ }^{17}$ are added, with the literary editorship of the novelist, and the critical and correspondent's work of Annie Howells Fréchette, ${ }^{18}$ we shall have in years nearly or quite a century of such fructifying labor within the spanned lifetimes of the Howells family. Perhaps during the stirring politics of the ' 50 's, no other village newspaper in the United States exercised as much direct influence as The Sentinel, of Jefferson, Ohio. It had distinguisht contributors, too. Representative Giddings was its volunteer editorial correspondent at the National Capital. The present editor jocosely says that he came into life "in the next room to a printing-shop, and has never got any farther away." Joseph was born at St. Clairsville,the family living in one room, and making and printing the paper in an adjoining one. The father, ${ }^{19}$ after the Republicans assumed control in Ohio, held a clerical position in the legislature for several years, so that his winters were past in Columbus. In 1869 he was elected state senator, and for nine

12 The only other reference to the St. Clairsville period of the Howells family life is contained in the epitaph which William Dean Howells wrote and had cut in the old printer's composing stone which was used for Joseph A. Howells' tombstone in the Jefferson graveyard: "To the memory of Joseph Alexander Howells. Born at St. Clairsville, O., I 832. Died at Auburndale, Fla., I 912 . American consul at Turks Island from 1905 to 1912. Printer and then editor, he imposed in pages on this stone, which he desired should mark his final resting place, the types of the Ashtabula Sentinel from 1851 to I $905 . .$. He was friend, brother, husband, father, son. Fill the whole limit of your space with praise, there needs no room for blame, blame there was none." Russell M. Bacon, "Ohio Honors Famous Literary Son Tomorrow," Cleveland Plain Dealer, February 28 , г937, p. то.

${ }^{13}$ The paper was sold to E. C. Lampson in 1909 and merged with the Jefferson Gazette.

14 See Note 3.

${ }^{15}$ William Dean Howells II, now living in Youngstown, Ohio.

${ }^{16}$ Four generations actually worked on the Ashtabula Sentinel, for William Dean Howells II was succeeded by his son, W. C. Howells. The latter became Associate Editor of the Plain Dealer of Cleveland, Ohio.

${ }^{17}$ Among these were the Ohio State Journal, the Cincinnati Gazette, the Cincinnati Commercial, the Cleveland Herald, the Ohio Farmer, etc.

18 Annie Howells married in Quebec, Antoine Leonard Achille Fréchette, the brother of the Canadian poet, Louis Honoré Fréchette (I 839-1908). Her novel "Reuben Dale" appeared in The Galaxy from December, 1875, to April, 1876 . She also contributed articles on Canada to Harper's. She died in 1938.

${ }^{19}$ William Cooper Howells was connected with Whig papers in Hamilton, Dayton, Ashtabula, and Jefferson, Ohio. He acted as Clerk of the House of the Ohio Legislature. He was never a state senator but was sent to Quebec as consul in 1874 and to Toronto in 1878 . He bought a farm on the James River in 1884 , but was not successful as a farmer. 
years afterward he served as United States consul at Quebec and Toronto. His daughter Annie, now Mrs. Fréchette, was married at Quebec in 1874; and Victoria at Toronto, shortly before the father resigned and moved with Amelia, Henry, and this married daughter to Virginia. After Victoria's death he returned to Jefferson.

The Mulholland marriage was not a happy one, and the husband, who left their home near Richmond for the ostensible purpose of a business trip to Alabama, has not since been seen or heard from by any of the family. The wedded life of Annie Howells Fréchette-herself a brilliant writer-is one of harmony and happiness. Achille Fréchette is a member of an old French family resident for 200 years in "New France." Like most of the college-bred French-Canadians, he studied law, tho not now or for long continuing in practise. He early turned his attention to journalism both in the United States and as editor-in-chief of a French paper publisht in Ottawa. He was so engaged at the time of his marriage to Miss Annie Howells. In 1874 he was appointed an official translator to the Canadian Parliament, and the family have lived in the vicinity of Ottawa since then. Annie Howells Fréchette is gracefully known in literature, as will soon be again recognized by the publication in book form of "Reuben Dale," a serial novel that appeared in the old Galaxy, as well by a collection of short stories which will soon be laid before the public. Her husband is an artist of fine ability, and his portraits are becoming widely recognized.

William Dean and Eleanore Howells have two children living,-Winifrid, born in Venice, having died in early girlhood. John Mead and Mildred Howells are the delight of their beautiful home and friends, and Miss Mildred has already achieved reputation, having illustrated successfully and tastefully some of her father's poems and works. ${ }^{20}$ The home of Samuel C. Howells at Washington is enlivened by four girls and one boy. The family in Jefferson consists of three, the oldest of whom will succeed his father on The Sentinel, being named after his author-uncle.

All the Howells have possest and shown literary ability in some notable degree. Victoria was the author of a well-conceived and written drama, entitled "The Sheriff's Daughter," which Actor Crane offered to accept if certain changes were made for stage purposes. Miss Amelia, engrost in the care of her invalid brother, has not done the work of which she is known to be capable. Mrs. Fréchette has served a full apprenticeship to the literary craft, and is now esteemed, and justly, a full working member.

There remains at the Jefferson home a considerable number of manuscripts left by the father; many essays, a little collection of songs and simple lyrics; lectures and addresses, many of these being religious in character. One address, historical in character, is a valuable monograph on printing. ${ }^{21}$ It was publisht in Scotland some years since, and is to be republisht at no distant day. He also left behind a charming but unfinisht volume on Ohio pioneer days.

${ }^{20}$ Mildred Howells ( $1872-$ ) illustrated magazine articles for her father. See especially "A Little Girl Among Old Masters," Harper's Monthly, November I 5, I 883.

21 We have been unable to find any other reference to this publication. 
In Jefferson and among his neighbors and friends on the Western Reserve the public good will that attended the father has followed his successor, Editor Joseph A. Howells, whose useful civic life has run close upon the kindly footsteps of the father. Joseph has taken great interest in education, serving as school trustee, in the town and county board of education, and as town councilman also. He has long been identified with the famous Wilberforce University, and is now president of the normal and industrial department. Samuel Cooper Howells, now resident in Washington, where he was for a considerable time connected with the proof-reading division of the government printing-office, is a printer by occupation. He was an active country editor, and sealed his citizenship with two years' fighting service in the Union Army. The youngest brother, John Butler, ${ }^{22}$ was the first to die in the family, and one of the poet-brother's finest pieces of work was the elegy sent home from the Venice consulate, of which the mother said: "What William writes from his heart is always his best."

The Sentinel office was the village exchange-the center of secular activity, the grave, quiet editor, always cheerful and kindly withal, being always the persuasive and controlling presence. He was a personal force. As I recall hima man in the mid-fifties, of rather slender figure, barely of middle stature, slightly stoop-shouldered, giving you the feeling of an enduring, nervous, but not muscular physique. His ways were quiet, his speech rather slow, with a touch of quaint and aphoristic wit therein. Mr. Howells left behind him in manuscript the partly finisht recollections of his life. His son William has added a valuable contribution to our pioneer literature by publishing the completed parts-“"Ohio in 1813-40"23 (Robert Clarke Co., Cincinnati),accompanied by an introduction and a brief closing chapter from his own pen.

My first meeting with William Dean Howells was a brief one, as he came on a flying visit from Columbus, Ohio, during the earlier months of $\mathbf{1} 86 \mathbf{1}$, and I happened to stay over a night while on a western trip. He was then editorially employed on The Ohio State Journal, ${ }^{24}$ and had already made his mark among the younger and brighter brains of the land by his little and joint volume with John J. Piatt ("Poems of Two Friends"), ${ }^{25}$ and among men like me, deeply immerst in Northern and stalwart agitation, by his life of Abraham Lincoln.

My second meeting was in September, I86I, and was almost as brief personally - for he was leaving for Venice as consul, and I for army service in the distant West. I still have the little Spanish-and-English pocket-dictionary he gave me. What my token was, has slipt from memory. The recollections are faint but lasting - perfumed with the idea of a grave but pleasant-faced, cheery,

${ }^{22}$ John Butler Howells died "with the first song of the birds," as his brother William Dean Howells wrote, Wednesday morning, April 27, 1864. Howells' "Elegy on John Butler Howells" is published in Poems (1 873), pp. 100-104.

${ }^{23}$ Recollections of Life in Ohio, from ${ }_{18} \times 3$ to 1840 , by William Cooper Howells, with an introduction by his son, William Dean Howells. Cincinnati, I 895 .

${ }^{24}$ Howells worked for the Ohio State Journal as a book reviewer, writer of literary notices, and news editor.

${ }^{25}$ This volume was published in 1860 . See Rudolf and Clara Kirk "Poems of Two Friends," Journal of the Rutgers University Library, IV, 33-44. 
and earnest-voiced young man, who managed to fill for me the presence I had conceived of the writer of "The Pilot's Story," ${ }^{\text {"26 }}$ as well as of the son and brother I had heard so tenderly yet proudly referred to in that circle of loving unity-the Howells' home at Jefferson.

The mother, Mary Dean Howells, was Pennsylvanian by birth, with ScotchIrish blood on her father's side, and the sturdy German sense and physique on

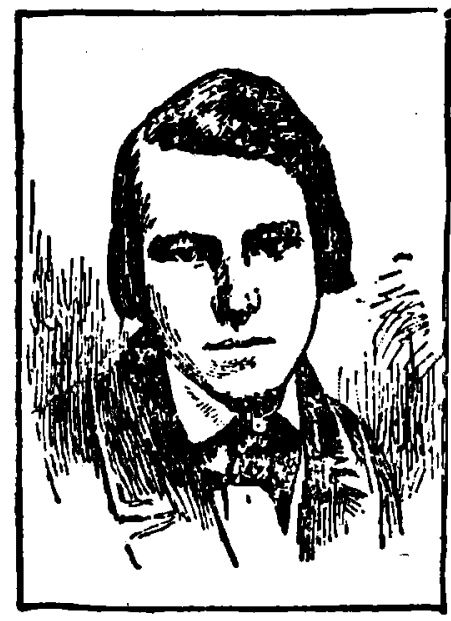

W. D. HOWELLS

(From a photograph taken about $1856-7$.

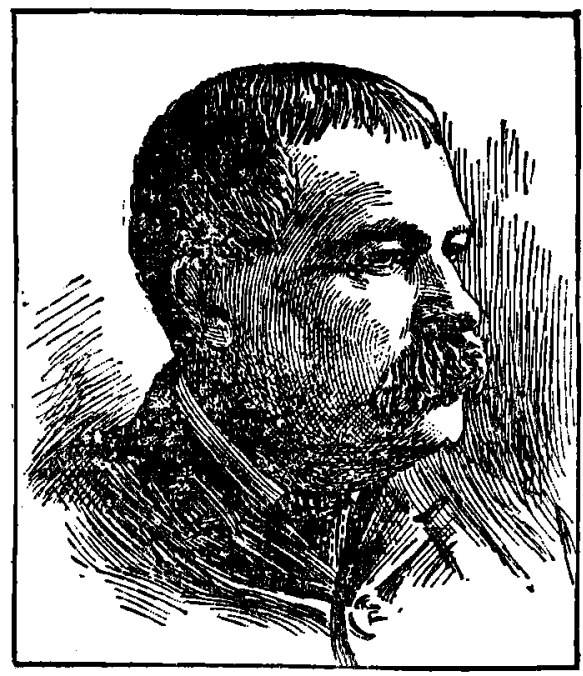

W. D. HOWELLS.

("A good picture of Will.")

the mother's. A very motherly, quiet, calm-mannered, sweet lady was Mrs. Howells when first I had the honor of friendly admission to that home circle. "As a young girl," writes one of her daughters, "I remember how imprest I used to be by the ease with which my mother talkt. She used always to seem to know just what to say- to strangers as well as those whose tastes she knew. People always found her ready to listen to their troubles and sorrows, and to help them find a way to bear or remove them." But her sympathy did not lead her to approve of "complainers," and "I remember that we children were never allowed to indulge in the luxury of grumbling or fault-finding." In the mother's cye "bad tempers" were not altogether the children's fault, but if they failed to control them, that was something for them to be heartily ashamed of. The mother's pure-mindedness was felt through the whole circle and in all her life. My own impression of that superb quality is almost as clear as that of the gifted daughter, who reminds me of the fact. It was prominent also in the mentality of the eldest of her girls-Victoria, and it belongs to all the family. The novelist illustrates it vividly in every page he writes, and I recall that the quiet proof-reader at Washington dwells in memory for his singular and simple modesty of manner and cleanliness of

${ }^{26}$ This poem first appeared in the Atlantic, September, 1860. 
speech, if I may so phrase it. Possibly the singularly intimate and saddened dependence of the stricken brother Henry accounts for very much of that which is indicated, not said, in this reference. The exquisite tribute the Howells all pay, in the many references with which I have been honored and endowed for use in this paper, tempts me almost too strongly; their words are so much more than any that follow the shadows of memory. In writing of the mother, one says: "I remember how in the far back days, when our young people would grow rebellious over our narrow surroundings, mother, while always sympathizing with our longings for a wider sphere, would often quote to us, 'From our own selves our joys must flow, ${ }^{27}$ and thus make us feel that happiness, after all, lay within."

The home circle at Jefferson was always cheerful. The voices therein were light-hearted and happy, even tho all felt the shadow of the sorrow brought by their brother's blighted life. The humorous side of things, I recall, was always a feature of their intercourse; each of them was ready to entertain and all were fraternally enjoyable. A small calamity was turned to sunshine, and sorrow became tender, so that cynicism or sarcasm had no place in their midst. The dear house-mother was a faithful comrade. The poet owes much of his disposition to retouch and refine to the mother's constant objection to poorly finisht work. She had fine tastes in literature. All the early writings were placed under her review and all were the better for it. The father's editorials and the son's early lyrics alike were read to and criticized by the gentle-faced and sweet-voiced mother. What wonder that these children all glow with the thronging recollections; that they are all tender, too, in their memories of the "dear father-man," as one quaintly and lovingly writes.

The Deans are known in early Pennsylvania annals; the family are still residents of Harrisburg and Pittsburg. Mr. Howells met his wife in the neighborhood of Steubenville, Ohio, and they were married July 10, I831, she being 20 years of age and he in his 25 th year. The mother died in the early ' 70 's, ${ }^{28}$ never having fully recovered from the shock of her youngest son's death.

There is but one member more to be mentioned, Henry, the helpless son, whose saddened existence has through all the years given to this home and family the crown of unselfish service and unremitting duty. As a child he manifested fine traits and was gifted with beauty of feature and form. The evidence of this still remains in his 6oth year ${ }^{29}$ as proof of the home tradition. The charm of face and expression is the wonder still of all alienists who have known him. A man of handsome physique, he is in ways and character a simple and almost helpless child. Scarlet fever and a fall produced his misfortune, and yet his brain is not wholly unexpressive. In reading Maartens' "God's Fool,"30

27 "From our own selves our joys must flow." This line appears in The Fireside by the English poet, Nathaniel Cotton (I 705-1 788).

${ }^{28}$ This date is incorrect. Mrs. W. C. Howells died in 1868.

${ }^{29}$ Since Howells himself was 60 in 1897 , the age given here for Henry is obviously incorrect.

${ }_{30}$ Maartens was the pseudonym of Jozua Marius Willem van der Poorten-Schwarts (1858-1915), whose Novel God's Fool was published in I892. 
I have been compelled to recall Henry Howells to my memory. After the mother's death, the father, with his daughters' willing aid, took up entirely the loving care, and when they went to Quebec, Henry was also a resident of the American consulate. The parents were never separated from him except by death, and the sister who remains unmarried holds this life-task as a constant benediction instead of a burden. In childish years Henry was fond of rhythmic sounds and melody; in his clouded ones, music has often soothed him into quiet. "His life," writes one who has cared for him constantly, "has been that of an untutored child, innocent and pure." Through all the dim blight, this has been the controlling fact. Preserved by the watchful love of those about him until now he sits or moves through the lonely and peaceful home with a calm and dignified demeanor that fuses pity into a pathetic respect.

What more may be said? Much, indeed, if space and circumstance warranted. My own disjointed recollections - for work and living sunders association-would easily run to the making of many pages. It is only essential to repeat that this home circle has been filled with such sincere living that "The Traveler from Altruria"31 was a natural growth. All its memories are endowed with a wholesome personal charm, such as springs only from forces that are spiritually sympathetic. This is apart, too, tho a part of the distinctive and copious measure of intellectual power all of the Howells family are endowed with. It is the sincerity of soul and upright being and dying of all that must give lasting grace to the fame that now clusters around the common name. That fame is already a part of our Saxon speech-associated with the "household words" that make our mother-tongue so vibrant and masculine, yet so homely and sweet.

\section{Washington, D. C.}

Richard J. Hinton

${ }^{31}$ The Traveler from Altruria, by William Dean Howells, a utopian romance published in 1894 .

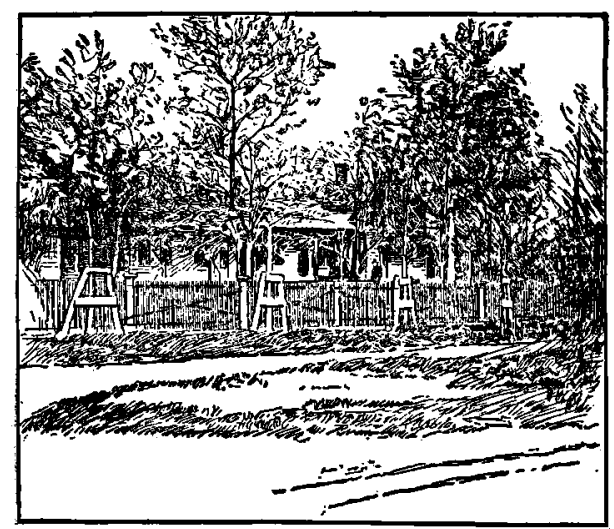

THW HOWHLLS "нOME HOCSE" $A T$ JRB FHRSON (1860). 